\title{
Scaffolding Problem Solving in Teaching and Learning the DPACE Model - A Design Thinking Approach
}

Malliga K. Govindasamy*

International Languages Campus, Kuala Lumpur, Institute of Teacher Education

Ngu Moi Kwe

International Languages Campus, Kuala Lumpur, Institute of Teacher Education

*Corresponding Author: mallikagovin@ipgm.edu.my

Received : 2019-11-21

Rev. Req : 2019-12-10

Accepted : 2020-01-03

DOI: $10.46303 /$ ressat.05.02.6

Govindasamy, M. K., \& Kwe, N. M. (2020). Scaffolding Problem Solving in Teaching and Learning the DPACE Model - A Design Thinking Approach. Research in Social Sciences and Technology, 5(2), 93-112. doi.org/10.46303/ressat.05.02.6

\begin{abstract}
Problem solving is a basic skill needed to function effectively in the working environment. Teachers are no exception to this professional demand. It is of utmost importance for teacher education programs to prepare pre-service teachers with this fundamental competency. The DPACE model is a preliminary effort by two teacher educators to enhance the problem-solving skills among pre-service teachers. The model was developed using the design thinking approach with reference to Vygotsky's constructivism and grounded by questions as scaffolds to facilitate internalization of knowledge that teachers need to assist them in addressing and expanding their problem-solving boundaries. The main structure of the model consists of five domains developed with reference to computational thinking concepts. Each domain consists of open-ended questions formulated according to Bloom's ordering of cognitive skills, taking pre-service teachers progressively toward better understanding of the problem and creating an efficient solution. This model was applied among 62 pre-service teachers enrolled in the TSLB3152 course at the Teacher Education Institute International Languages Campus, Kuala Lumpur, Malaysia. In total, $86.67 \%$ of the respondents reported that the DPACE model helped them in their problem-solving task and almost $78 \%$ of them scored an A grade in their coursework tasks facilitated using the DPACE model. Efforts are needed to further refine the questions and field test the model in other courses or situations with the hope that this ongoing teacher education effort will create a paradigm shift in the quest toward mastery of 21st century skills among pre-service teachers.
\end{abstract}

Keywords: DPACE model, problem-solving skills, scaffolding, computational thinking, teaching and learning 
Govindasamy, M. K., \& Kwe, N. M. (2020). Scaffolding Problem Solving in Teaching and Learning the DPACE Model - A Design Thinking Approach.

\section{Introduction}

Problem solving is defined as the mental process of working through the details of a problem to reach a justifiable solution. In academia, it is considered as a cognitive process that directs the learners to use and combine various cognitive functions in an effort to solve a novel problem. It includes representing, planning, executing, and self-regulating the problem task (Mayer \& Wittrock, 2006, as cited in Haataja et al., 2019). Dick, Carey, and Carey (2014) asserted that problem solving is the highest order of cognition that facilitates innovative knowledge practices. Problem solving is not a skill or knowledge merely limited to academics but relates strongly to the challenges of the workplace, where it is needed to support the delivery of solutions. The knowledge-based global economy demands acute critical thinking to solve real-world problems. Specific to the needs of the workplace, the Malaysian Educational Blueprint (Ministry of Education, 2013) has emphasized initiatives to develop and enhance the key competencies that enable students to master problem solving. However, the general perception of employers with regard to problem solving indicates that Malaysian graduates generally lack these life skills and are not able to think critically and creatively in new situations (Ministry of Education, 2015).

The teaching profession in Malaysia is no exception to the above dilemma. The inability to interrogate instructional problems is one of the many challenges teachers face in their professional practices. It is very important for teachers to facilitate students' learning in an efficient manner, and this requires teachers to critically reflect on their practices. Most teachers lack critical and creative thinking despite the many initiatives by the Ministry of Education to foster these skills through professional development programs. Since 1994, the Teacher Education Division, through the adoption of the "Boston Model" or the infusion model, incorporated higher-order thinking in the teacher education programs (Nagappan, 2001). The pre-service teachers were also exposed to other models, including the CoRT Thinking Tools, yet findings indicate that the teachers still lack the ability to apply accurately higher-order thinking in their actual professional practices (Kuldas, Hashim, \& Ismail, 2015, as cited in Dewitt, Alias, \& Siraj, 2016). Nagappan (2001) and Suhaili (2014) concluded that in order to have a better understanding of critical thinking and problem-solving strategies, teachers, both novice and experienced, need to be trained in instructional strategies. While some teachers, through their many years of experience, may have acquired the ability to independently solve instructional problems effectively, others might need assistance to improve their competency in solving problems.

\section{Problem Statement}

The course Digital Innovation in Teaching and Learning (TSLB3152) is a two-credit course offered in the Graduate Teacher Education Program. The course learning outcome is to enable pre-service teachers to creatively and innovatively solve instructional problems using digital tools and applications. The course aspires to develop pre-service teachers' problem-solving skills and empower them to become better problem solvers in their profession. 
Govindasamy, M. K., \& Kwe, N. M. (2020). Scaffolding Problem Solving in Teaching and Learning the DPACE Model - A Design Thinking Approach.

The main coursework task requires pre-service teachers to innovatively solve one teaching and learning problem they encountered in the teaching of their option subject during their practicum sessions in schools. The TSLB3152 course is delivered over a period of one semester after the pre-service teachers have undergone practical teaching in the earlier semester. Prior to the integration of the proposed problem-solving strategy, the pre-service teachers did not have a structured approach in addressing the identified instructional problems. The usual problem-solving approach employed in the course involves encouraging them to brainstorm in groups to identify possible new and better strategies to solve the said problem. This was consistent with Asimow's (2015) recordings on the common problem-solving approach in which individuals identify the problem, consider options for solutions, sieve through the possibilities and pick one, try it out, and find out if it worked. For the most part, the prediction strategy of "what would happen if ..." is used before defining the end goal for each stage of problem solving. This analytical and deductive thinking process is done to help them select the best solution to the problem before embarking on developing the product as a solution. The course proforma recommended some generally established problem-solving models; however, these models did not fit the specific requirements of the coursework task.

During the observation of the practicum session, it was discovered that the pre-service teachers failed to demonstrate a sound knowledge of problem solving in their teaching practices. The reflective writing records showed that their focus was more on addressing nonteaching-related problems that occur in the class and that they were unable to think creatively about ways to solve the actual teaching- and learning-related problems.

The final assessment of the coursework outcome (solution products) showed that a major percentage of their work was at the augmentation and modification level (Figure 1). The solutions created were found to be mainly direct substitutes with a functional improvement for existing teaching and learning objects. A digitized version of the regular learning objects in use, such as e-story, animated posters, e-worksheets, and interactive Powerpoint slides with enhanced features such as games and online assessment tools, were produced as the ultimate solution.

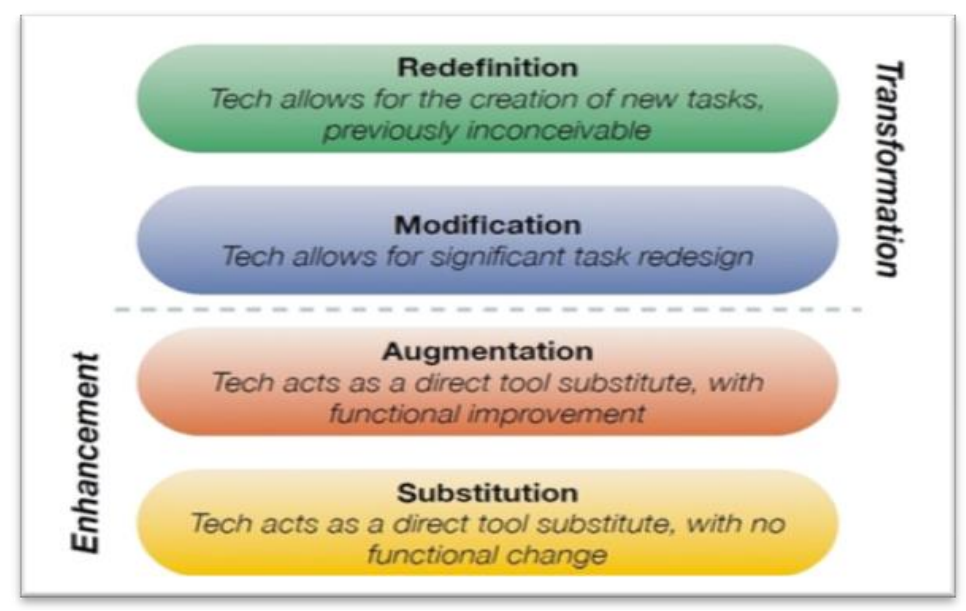

Figure 1: SAMR Model (Puentedura, 2014) 
Govindasamy, M. K., \& Kwe, N. M. (2020). Scaffolding Problem Solving in Teaching and Learning the DPACE Model - A Design Thinking Approach.

Generally, the assessment of performance in the TSLB3152 course showed the pre-service teachers' inability to address the "real" problem effectively. Most of the solutions created had gaps and lacked generalizability. Findings from a Likert Scale survey that solicited the preservice teachers' perceived competence levels in solving instruction-related problems indicated inadequate knowledge and skills in addressing problems and generating a justifiable solution. In sum, the pre-service teachers need guidance to frame their thoughts and cognitions in identifying problems and analyzing situations and challenges so that they are able to generate justifiable solutions to the teaching and learning content-related problems.

\section{Purpose of the Study}

This study intends to validate the effectiveness of the DPACE model in facilitating the preservice teachers in planning and executing a solution for the identified instructional problem. The objective of the study is twofold: i) to design and develop a structured problem-solving model using questions as a scaffold, and ii) to validate the effectiveness of the model in facilitating pre-service teachers' problem solving ability.

The study probes into three main aspects, namely:

1. Identify the dimensions for the proposed problem-solving model;

2. Build a series of open-ended questions that form the scaffold within the dimensions of the proposed model;

3. Validate the effectiveness of the designed model in facilitating problem solving among pre-service teachers.

\section{Literature Review}

A learner's developmental level consists of (i) the actual developmental level, at which the learner possesses the ability to independently perform a task, and (ii) the potential developmental level, where the learner accomplishes a task through guidance and assistance from a more competent adult or capable peer (Vygotsky, 1978). Vygotsky believed that appropriate supportive instructional activities for a task, when provided to a learner at the potential developmental level (Zone of Proximal Development or ZPD), will "boost" the ability to accomplish the task. One of the ways to lead the learner through the ZPD is through scaffolding.

Instructional scaffolding is a systematic process through which a more knowledgeable person adds supports for students in order to move them progressively toward stronger understanding and ultimately greater independence in learning. Wood, Bruner, and Ross (1976), as cited in McLeod (2019), highlighted that in scaffolding, the more competent person must control the elements of the task that are initially beyond the learner's capability, permitting the novice to concentrate upon and complete only those elements that are within his or her range of competence. In other words, introducing individual tasks within the dimension of the learner's competence can serve as scaffolds that eventually help learners 
Govindasamy, M. K., \& Kwe, N. M. (2020). Scaffolding Problem Solving in Teaching and Learning the DPACE Model - A Design Thinking Approach.

complete the whole learning task. Such a scaffolding strategy will be beneficial for the novice or inexperienced teacher, providing them with the necessary support and guidance at the initial stage so that they will be able to organize their thoughts, develop specific knowledge or skills that bridge their ZPD, and eventually facilitates problem solving. Consistently, literature documented the use of scaffolding to help improve pre-service teachers' specific reflective thinking and writing (Lai \& Calandra, 2010, and Mair, 2012, as cited in Ching, Yang, Baek, \& Baldwin, 2016).

The intent of scaffolding is to guide the building of knowledge from the ground up (concrete to abstract) in order to bridge foundational knowledge to higher-level thinking and application. These cognitive skills, as described by Bloom (1956) and updated by Anderson et al. (2001), reflect the need to structure learning activities to develop students' higher-order potentials (as cited in Fisher \& Frey, 2010). Structuring the task as a means of scaffolding students' understanding was also put forth by Applebee and Langer (1983), who viewed a structured environment as a strategy to sequence the thoughts of the students when approaching a task. A clearly structured approach, according to Surgenor (2010), enables students to prioritize information and identify links and connections between concepts and ideas and from one level to another. Surgenor (2010) further emphasized the need to systematically and logically sequence the information aided with the explicit sign-posting of key issues to increase comprehension and enable students to separate the "wood from the trees." This phrase suggests that well-structured details of scaffolding allow students to address the minor details of the task and not just view it in entirety.

A number of tools (visuals and verbals) have been identified by scholars and researchers as aiding formal scaffolding. These include concept maps, word webs, graphic organizers, explanations, examples, hints, prompts, question cards, and question stems (Alibali, 2006). Alibali (2006) further posits that as the complexity of the content increases, a variety of scaffolds are required to accommodate the different levels of complexity to help students master the content. In such situations, teachers can opt for a combination of visual scaffolds with modeling of a skill or adapting a material/activity (Copple \& Bredekamp, 2009; Larkin, 2002), bringing students' attention to the task and jointly solving the problem or providing continuous motivation (Ragoff, 1990, as cited in Rodgers, 2004). Among all these, questioning received accolades as the most integral component of instructional scaffolding. Vygotsky (1978) posited questions as providing unique access to the learners' ZPD, directing teachers toward specific interventions in the scaffolding metaphor. Echoing this, Larkin (2002) prompted for questioning techniques to bridge the gap between what a learner knows and what the learner needs to know.

The significance of questioning as a high-level cognitive strategy is discussed explicitly by scholars and is well documented in the literature. Posing questions pertinent to a specific scope of knowledge works as a thinking stimulant and facilitates the learning process. Davoudi and Sadhegi (2015) highlighted the indispensable role of questioning in facilitating critical thinking and metacognitive skills. Guided questioning as a form of scaffold has been recorded as enabling students to elicit critical thinking (Coffey, 2014) and improving the depth of written 
Govindasamy, M. K., \& Kwe, N. M. (2020). Scaffolding Problem Solving in Teaching and Learning the DPACE Model - A Design Thinking Approach.

reflection (Moussa-Inaty, 2015). Dahl and Eriksen (2015) recommended open-ended questions as a means to create an environment of inquiry that allows students to produce higher levels of reflection. According to Sheninger (2018), placing accurate and properly phrased questions within a mental process's developmental structure can assist internalization, independence, and generalization of knowledge to other contexts.

Guiding students to move from the acquisition of knowledge to the application of knowledge and then to creation of knowledge is indeed a challenge; however, structuring the thinking process with well-designed questions can help to address this elusiveness. Deed (2009), as cited in Davoudi and Sadhegi (2015), asserts that structured questions can be viewed as a pedagogical tool for students to represent, organize, communicate, and conceptualize abstract ideas committed to their learning. In other words, rightly pitched questions at each cognitive level raise the thinking challenge. Applebee and Langer (1983) proposed that questions be structured around a model or framework that naturally sequences thoughts so as to extend and elaborate the knowledge the learner already possesses. This strategy will pave the way for development of new knowledge that will eventually bring the learner to function autonomously in that task and generalize the new learned knowledge to similar circumstances. Revell and Wainwright (2009) opined that a structured approach designed along a framework or a model helps students visualize the "big picture" of the task to be accomplished while progressively attending to minor details.

The design thinking approach (structuring of the thinking) as proposed in this study references the concepts of computational thinking. Computational thinking (CT) is broadly defined as a set of cognitive skills that draws upon certain logically ordered steps and dispositions placed within a problem-solving structure (Wing, 2006). The concepts of CT guide students to systematically organize their thought processes involved in problem solving so that the solutions are generalizable to the real world. CT is essential to the development of computer applications, but it can also be used to support problem solving across all disciplines.

\section{Research Methodology}

The study adapted the Design Science Research Methodology (DSRM) by Peffers, Tuunanen, Rothenberger, and Chatterjee (2007). Design science, as conceptualized by Simon (1996), supports a pragmatic research paradigm that calls for the creation of innovative artifacts to solve real-world problems. Thus, the DSRM was employed to guide the building blocks of this model, providing research directions and addressing the research objectives. Within this design, a combination of qualitative and quantitative methods via exploratory approach was applied to progress the study from the broader perspective to the required details. The details of the current study according to the various stages as recommended by the DSRM is shown in Figure 2. 
Govindasamy, M. K., \& Kwe, N. M. (2020). Scaffolding Problem Solving in Teaching and Learning the DPACE Model - A Design Thinking Approach.

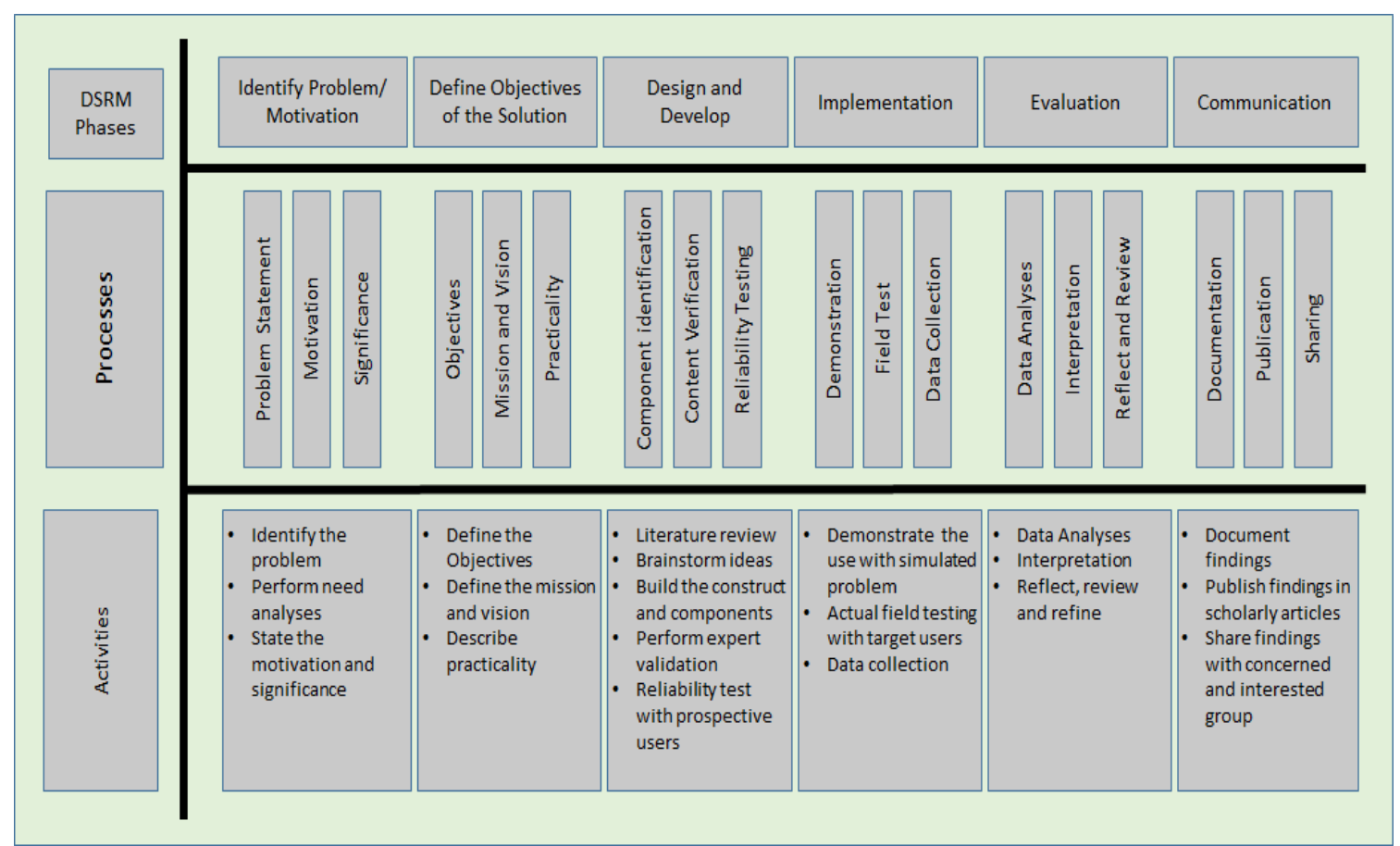

Figure 2: DSRM-based research phases and research activities (adapted from Peffers, Tuunanen, Rothenberger, \& Chatterjee, 2007)

The development of the model and the open-ended questions were grounded by critical analysis of relevant literature. The reliability and validity of the scaffold questions were established through advice and recommendations from experts in the field of assessment and evaluation. The validation of the designed problem-solving model was carried out using the cross-sectional (CS) approach. CS has been proven to be an effective method for providing a snapshot of the behaviors, attitudes, and perspectives of participants in a study (Gay, Mills, \& Airasian, 2009). A Likert-style questionnaire was used to solicit the pre-service teachers' perceptions of the usefulness of the model in facilitating the problem solving task. The questionnaire also carried open-ended questions to elicit the pre-service teachers' feedback on the usability of the model.

In total, 62 pre-service teachers from one cohort enrolled in the TESL degree program at the Teacher Education Institute International Languages Campus in Kuala Lumpur, Malaysia, participated in this study. The developed model was employed in the teaching of the TSLB3152 course. This course is offered in the sixth semester of the four-year degree program.

\section{Development of the DPACE Model}

The Zone of Proximal Development (ZPD), as posited by Vygotsky's Constructivist Theory (1976) and Bruner's Scaffolding Theory (Wood, Bruner, \& Ross, 1976), formed the ground for the model. The proposed model consists of two main components: i) progressive dimensions for problem solving, and ii) scaffolds. The dimensions were derived from the concepts of computational thinking and structured with relevance to the taxonomy of cognitive domains 
(Bloom, 1956). Numerous studies on problem-solving strategies have documented computational thinking as one effective approach to solve problems across various disciplines. The proposed model extends the CT problem-solving processes by adding relevant dimensions that relate to the ordering of cognitive processes. Figure 3 describes the building of the proposed model.

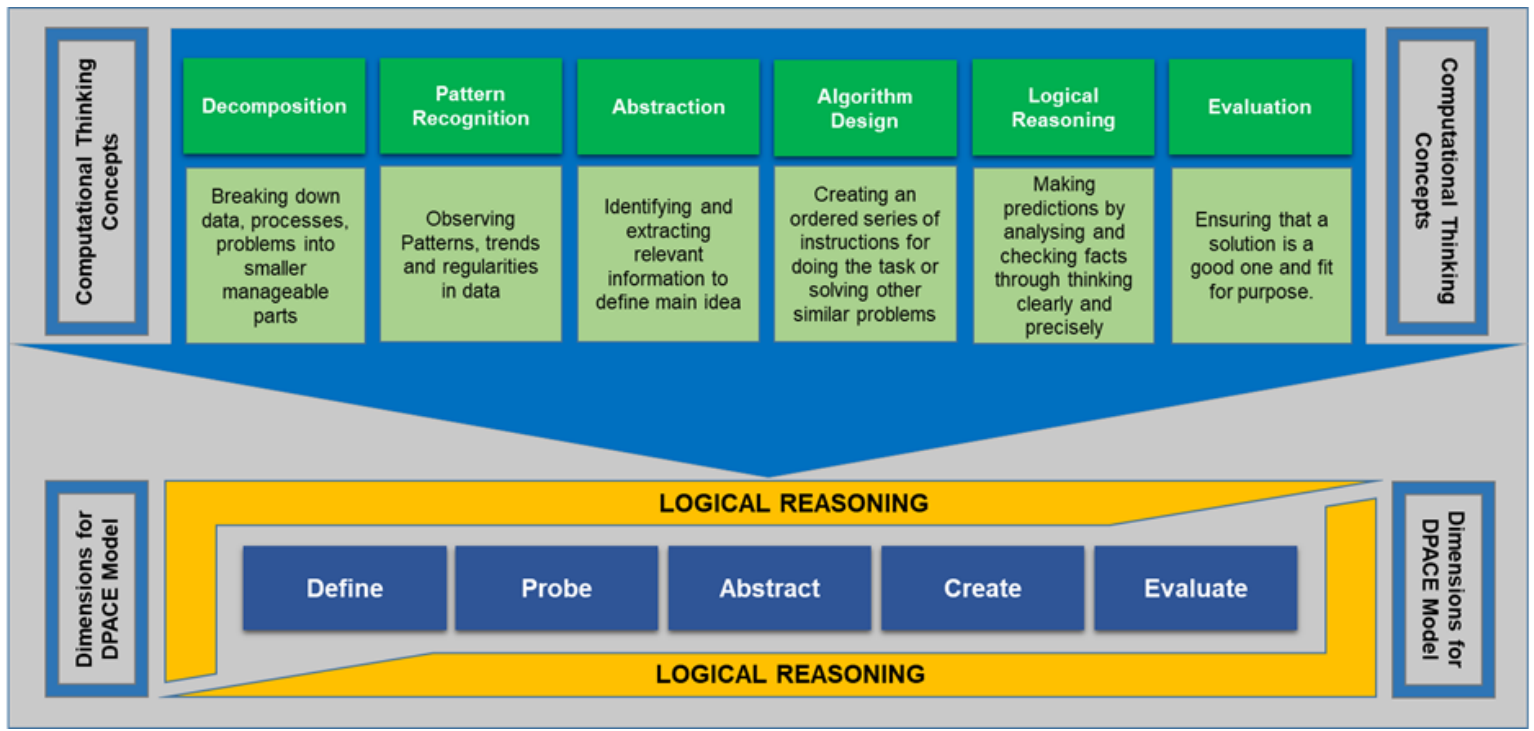

Figure 3: The dimensions of the DPACE model with relevance to the CT concepts

The structure of the problem-solving model is comprised of five domains related to the design thinking process, namely: i) Define, ii) Probe, iii) Abstract, iv) Create, and v) Evaluate. Each aspect of the domain was clearly defined using concepts adapted from the stages of thinking as postulated in CT. Each dimension is further reinforced with sign-postings that facilitate preservice teachers to comprehend their cognitive behaviors at each progressive level. Figure 4 shows the dimensions with the sign-posting phrases and statements. 


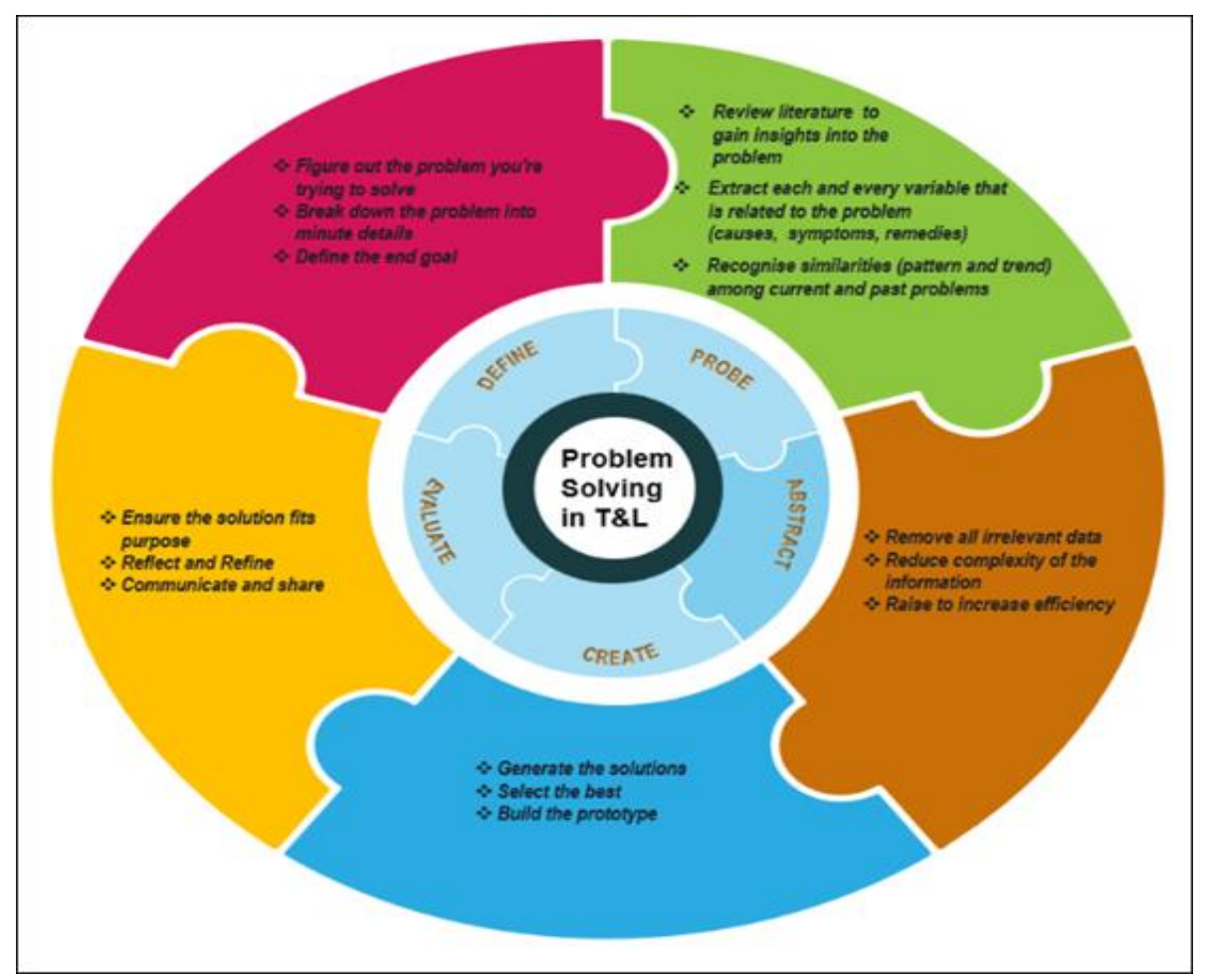

Figure 4: Dimensions of the model with sign-posting

The scaffolds consist of open-ended questions. According to Zwiers and Crawford (2011), open-ended questions elicit deeper thinking and offer the opportunity to produce original ideas. The open-ended questions were formulated based on the progressive levels according to Bloom's ordering of cognitive skills. The questions were verified for content validity and reliability. The internal consistency reliability of the question statements was estimated through a triangulation process among experts in the field of pedagogy and evaluation and assessment. This was done in order to establish the consistency of responses in terms of addressing the intended cognitive activities at each level of the continuum. Figure 5 shows the model's five domains mapped with scaffold questions that match the cognitive levels. 
Govindasamy, M. K., \& Kwe, N. M. (2020). Scaffolding Problem Solving in Teaching and Learning the DPACE Model - A Design Thinking Approach.

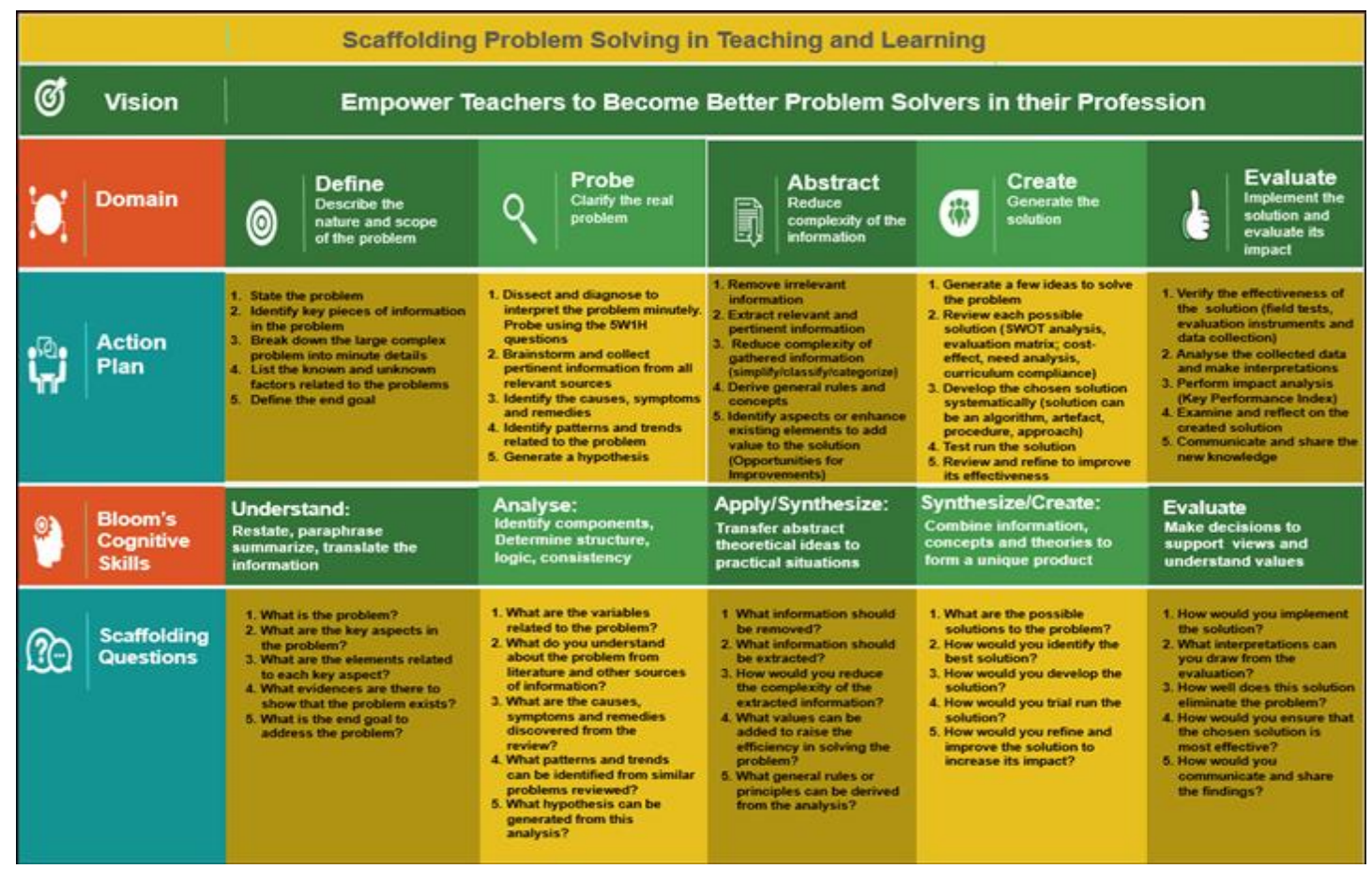

Figure 5: The DPACE model's five domains and the mapped scaffold questions

\section{Implementation of the DPACE Model}

The DPACE model was developed to enable pre-service teachers to effectively solve content teaching- and learning-related problems using questions as a scaffold. Prior to the actual field test, the selected sample of students was provided with a simulation using the model. Misinterpretations were clarified so that the students clearly understood the actual use of the model. Following this, the field test was carried out among the 62 pre-service teachers. These teachers used the model to create a digital solution to the problem identified during their practicum session. The teachers' perceptions of the usefulness of the model was solicited using an online survey questionnaire (see Appendix 1) generated using Google Form.

\section{Data Collection and Analyses}

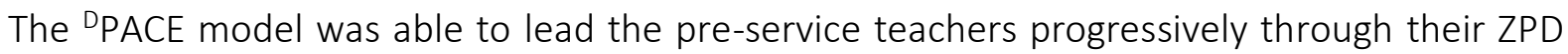
toward better understanding of teaching and learning problems and incrementally improve their problem-solving skills.

The assessment of their coursework task revealed that a good percentage of the products developed showed significant task redesign and can be categorized as transformative: modification and redefinition level as shown in the SAMR model (Figure 1). About $78 \%$ of this batch of pre-service teachers received an A grade in their coursework task (Figure 6). 


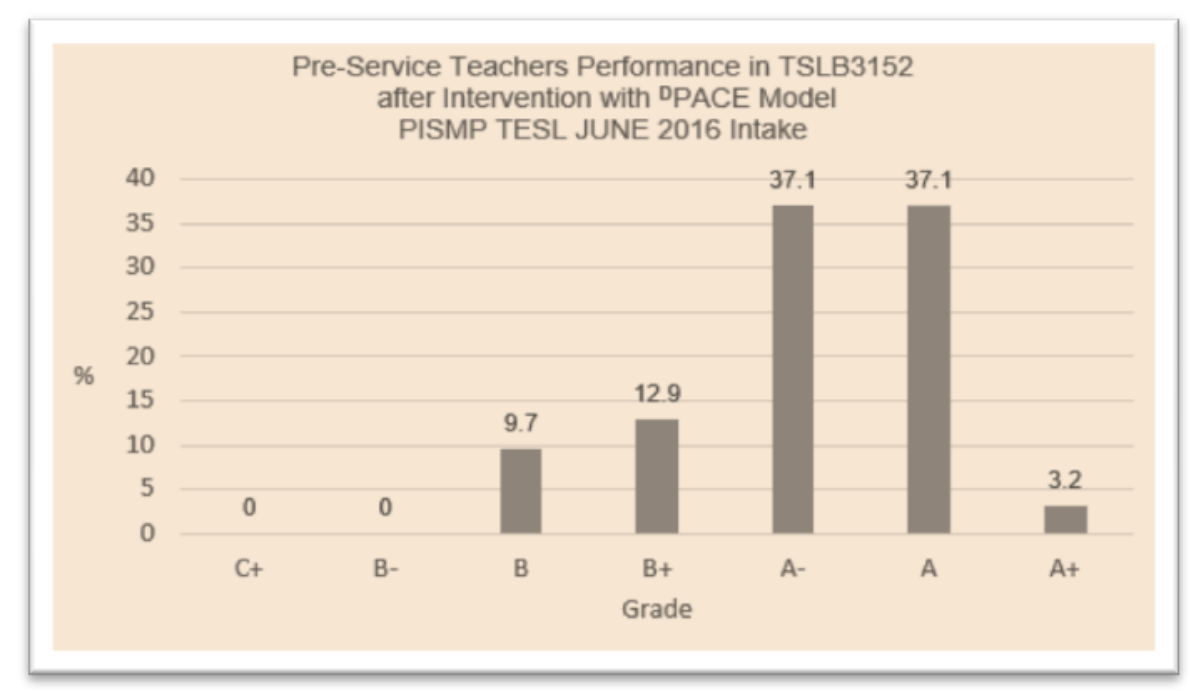

Figure 6: Student performance after intervention

The perceived benefit of the model by the pre-service teachers was solicited through a 15-item Likert Scale Questionnaire disseminated via Google Form at the end of the course. The analysis (see Appendix 2) revealed that on average, $86.67 \%$ out of the 58 respondents reported that the DPACE model helped them in their problem-solving task. Among the benefits stated, the highest percentage (94.74\%) agreed with the statement of "The questions helped me to organize my problem solving process systematically," with a mean score of 4.29 out of 5 with a standard deviation (SD) of 0.65. Next highest (92.11\%) agreement among them was for the statement of "I'm able to create a solution to the problem," followed by "The questions helped me to decompose the problems better" (89.47\% with a mean score of 4.24 and 0.7 SD). The lowest percentage of $73.68 \%$ agreement, with a mean score of 3.95 with a $0.77 \mathrm{SD}$, which can still be considered a high score, was for "I'm clear with the end goal of each domain."

The pre-service teachers were asked to provide suggestions/comments regarding the design thinking approach and the scaffolding questions. Comments provided by these teachers also support the findings stated above. Some of the comments are as follows:

- It's a thorough process of thinking, which made us aware of minor details in our problem. (R5)

- The structured approach with the 5 procedural steps helps to know the root problem in order to find the solution for it. (R9)

- The scaffolding question helped me to clearly identify problems and solve it. (R21)

- The questions are very helpful to prompt thinking of a deeper cause of the problem. (R29)

- It is a systematic way to guide our thinking as innovators. (R32)

Visual representations of data help organize and summarize research data. These representations can enhance the clarity and support for research findings (Dickinson, 2010). To provide insight related to the trends that emerge from the qualitative data retrieved from the survey, a word cloud was generated using a Google add-on application, Awesome Table. 
The product (Figure 7) demonstrates a fast and visually rich way to enable the researchers to have some basic understanding of the data at hand.

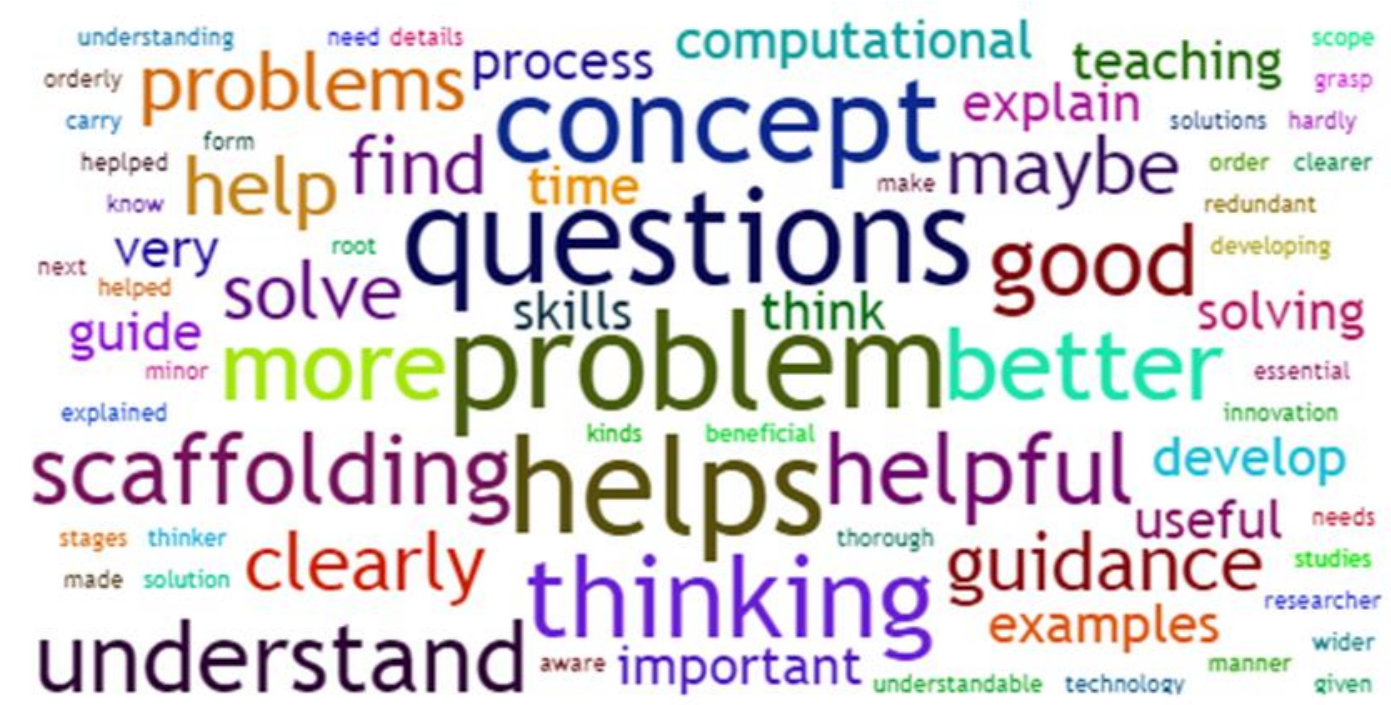

Figure 7: Patterns or trends that emerged from the pre-service teachers' comments/ suggestions regarding the DPACE model and the scaffolding questions

The bolder, larger words ("questions," "problems," and "helps") represent the overall preliminary perception of the pre-service teachers regarding the problem-solving model. However, while the word cloud provides an alternative for the researchers to explore and communicate the findings, it does not tell the whole story, as the size of the words reflect frequency, not importance or the exact context.

\section{Conclusions and Recommendations}

This exploratory study has provided an insight into the importance and need to scaffold problem solving. The pre-service teachers need a support structure that provides them with opportunities to use their problem-solving processes in meaningful learning contexts. By means of Define, Probe, Abstract, Create, and Evaluate questions being systematically offered in the scaffolding plan, a cognitive structuring of the solution process and hence an improvement of students' problem-solving competency were intended. As Hao Yang (2017) posits, follow-up and challenging questions are beneficial to develop students' thinking ability.

The strategic instrument, scaffolding questions as used in this model, is a scaffold designed specifically for problem-solving tasks in the teaching and learning contexts, to identify teaching and learning problems, and designing as well as creating innovative digital solutions. This study has shown significant results indicating the effectiveness of questioning as a scaffolding tool for problem solving, and it replicates the results of previous studies (DelMarcelle, 2017; McCarthy et al., 2016; Zheng \& Cao, 2017). Hence, the findings of this study may provide an important contribution to the literature on questioning techniques to be used in teacher education programs as well as provisions for professional development programs for in-service 
teachers. The findings may serve as a framework to support all levels of questioning categories in Bloom's taxonomy (Bloom, 1956).

The DPACE model is a powerful approach to thinking and problem solving, as the concepts are grounded in sound pedagogical theories. The structured and systematic approach will benefit not only the pre-service teachers and lecturers involved in the TSLB3152 course but also subjects, situations, or industries where the need to provide solutions to specific problems arises. In other words, the DPACE model is replicable. However, as the findings are limited to the context of this study, efforts are needed to further refine and simplify the scaffold questions. In addition, prior to generalization of the findings, the DPACE model needs to be field-tested in other courses in ongoing teacher education efforts to ensure a paradigm shift in pre-service teachers' thinking toward achieving 21st century skills. This shift is essential and significant in order to produce the skilled problem solvers that the world demands today.

\section{Success of the DPACE Model}

This DPACE model won a silver medal at the International Summit of Innovation and Design Exposition 2019 (INSIDE 2019) organized by the University of Malaya, Malaysia, held April 2930, 2019. 
Govindasamy, M. K., \& Kwe, N. M. (2020). Scaffolding Problem Solving in Teaching and Learning the DPACE Model - A Design Thinking Approach.

\section{References}

Alibali, M. (2006). Does visual scaffolding facilitate students' mathematics learning? Evidence from early algebra. Retrieved from http://ies.ed.gov/funding/grant search/ details.asp? ID $=54$

Anderson, L. W., Krathwohl, D. R., Airasian, P. W., Cruikshank, K. A., Mayer, R. E., Pintrich, P. R., Raths, J., \& Wittrock, M. C. (2001). A taxonomy for learning, teaching, and assessing: A revision of Bloom's taxonomy of educational objectives. New York: Pearson, Allyn \& Bacon.

Asimow, J. (2015). Maths at home: Bringing out the mathematician in every child. Retrieved from https://mathathome.org/scaffolding-for-problem-solving/

Bloom, B. S. (1956). Taxonomy of educational objectives, Handbook: The cognitive domain. New York: McKay.

Ching, Y. H., Yang, D., Baek, Y., \& Baldwin, S. (2016). Enhancing graduate students' reflection in e-portfolios using the TPACK framework. Australasian Journal of Educational Technology, 32(5), 108-122. Retrieved from https://doi.org/ 10.14742/ajet.2830

Coffey, A. M. (2014). Using video to develop skills in reflection in teacher education students. Australian Journal of Teacher Education, 39(9), 86-97. Retrieved from http://dx.doi.org/10.14221/ajte.2014v39n9.7

Copple, C., \& Bredekamp, S. (2009). Developmentally appropriate practice in early childhood programs. Washington, DC: National Association for the Education of Young Children.

Dahl, H., \& Eriksen, K. A. (2015). Students' and teachers' experiences of participating in the reflection process "THiNK." Nurse Education Today.

Davoudi, M., \& Sadhegi, A. N. (2015). A systematic review of research on questioning as a highlevel cognitive strategy. English Language Teaching, 8, 76-90. Retrieved from http://dx.doi.org/10.5539/elt.v8n10p76

DelMarcelle, J. (2017). Examining the significance of scaffolding on student teachers' written reflections: A qualitative case study. Theses and Dissertations, 1486. Retrieved from https://knowledge.library.iup.edu/etd/1486

Dewitt, D., Alias, N., \& Sirah, S. (2016). Problem solving strategies of Malaysian secondary school teachers. Educational Technology World Conference, 31 July - 3 August, Bali, Indonesia. 
Dick, W., Carey, L., \& Carey J. (2014). Systematic design of instruction (8th ed.). Amazon.com: Kindle Store.

Fisher \& Frey. (2010). Guided instruction. Scaffolds for learning: The key to guided instruction. Retrieved from http://www.ascd.org/

Gay, L. R., Mills, G. E., \& Airasian, P. W. (2009). Educational research: Competencies for analysis and applications (9th edition). Upper Saddle River, NJ: Prentice Hall.

Hao Yang. (2017). A research on the effective questioning strategies in class. Science Journal of Education, 5(4), 158-163. Retrieved from http://www.science publishinggroup.com/journal/paperinfo?journalid=197\&doi=10.11648/j.sjedu.201705 04.16

Haataja, E., Moreno-Esteva, E. G., Salonen, V., Laine, A., Toivanen, M., \& Hannula, M. S. (2019). Teacher's visual attention when scaffolding collaborative mathematical problem solving. Teaching and Teacher Education, 86. doi.org/10.1016/j.tate.2019. 102877

Larkin, M. (2002). Using scaffolded instruction to optimize learning. Retrieved from http://www.vtaide.com/png/ERIC/Scaffolding.htm

McCarthy, P., Sithole, A., McCarthy, P., Cho, J., \& Gyan, E. (2016). Teacher questioning strategies in mathematical classroom discourse: A case study of two grade eight teachers in Tennessee, USA. Journal of Education and Practice, 7(21), 80-89.

McLeod, S. A. (2019). What is the zone of proximal development? Retrieved from https://www.simplypsychology.org/Zone-of-Proximal-Development.html

Ministry of Education. (2013). The Malaysian education blueprint 2013-2025: Preschool to post secondary. Putrajaya: Malaysia.

Ministry of Education Malaysia. (2015). The Malaysian education blueprint 2015-2025 (Higher education). Putrajaya: Malaysia.

Moussa-Inaty, J. (2015). Reflective writing through the use of guiding questions. International Journal of Teaching and Learning in Higher Education, 27(1), 104-113. Retrieved from https://files.eric.ed.gov/fulltext/EJ1069801.pdf

Nagappan, R. (2001). The teaching of higher-order thinking skills in Malaysia. Journal of Southeast Asian Education, 2(1), 1-22.

Peffers, K., Tuunanen, T., Rothenberger, M. A., \& Chatterjee, S. (2007). A design science research methodology for information systems research. Journal of Management Information 
Systems, 24, 45-77.

Puentedura, R. R. (2014). SAMR model and TPCK: A hands-on approach to classroom practice. Retrieved from http://www.hippasus.com/rrpweblog/ archives/2014/12/11/SAMRandTPCK_HandsOnApproachClassroomPractice.pdf

Revell, A., \& Wainwright, E. (2009). What makes lectures unmissable? Insights into teaching excellence and active learning. Journal of Geography Higher Education, 33(2), 209-223.

Rodgers, E. M. (2004). Interactions that scaffold reading performance. Journal of Literacy Research, 36(4), 501-532.

Sheninger, E. (2018). A principal's reflections: Reflections on teaching, learning, and leadership. Retrieved from http://esheninger.blogspot.com/2018/02/ scaffolding-questions-todevelop-deeper.html

Simon, H. A. (1996). The sciences of the artificial (3rd ed.). Cambridge, MA: MIT Press.

Suhaili, A. (2014). Exploring teachers' experiences on integration of higher order thinking skills (HOTs) in teaching of science. Masters thesis, Universiti Malaysia Sarawak, UNIMAS. Retrieved from http://ir.unimas.my/id/eprint/ 6789

Surgenor, P. (2010). Structuring a teaching session. UCD teaching and learning resources. Retrieved from http://www.ucd.ie/teaching/t4media/UCDTLT 0023.pdf

Vygotsky, L. S. (1978). Mind in society: The development of higher psychological processes. Cambridge, MA: Harvard University Press.

Wing, J. M. (2006). "Computational thinking" (PDF). Communications of the ACM, 49(3), 33. Retrieved from https://doi:10.1145/1118178.1118215

Wood, D., Bruner, J., \& Ross, G. (1976). The role of tutoring in problem solving. Journal of Child Psychology and Child Psychiatry, 17, 89-100.

Zheng, W., \& Cao, Y. H. (2017). Effects of scaffolding creative problem solving through question prompts in project-based community service learning. 122nd ASEE Annual Conference and Exposition June 14-17, Seattle, WA. Paper ID \#13970. Retrieved from https://www.asee.org/public/conferences/56/papers/13970p/download

Zwiers, J., \& Crawford, M. (2011). Academic conversations: Classroom talk that fosters critical thinking and content understandings. Portland, ME: Stenhouse Publishers. 
ressol.

Research in Scial sciences and Technologr

volume 5 Issue 2,2020

Govindasamy, M. K., \& Kwe, N. M. (2020). Scaffolding Problem Solving in Teaching and Learning the DPACE Model - A Design Thinking Approach.

Appendix 1

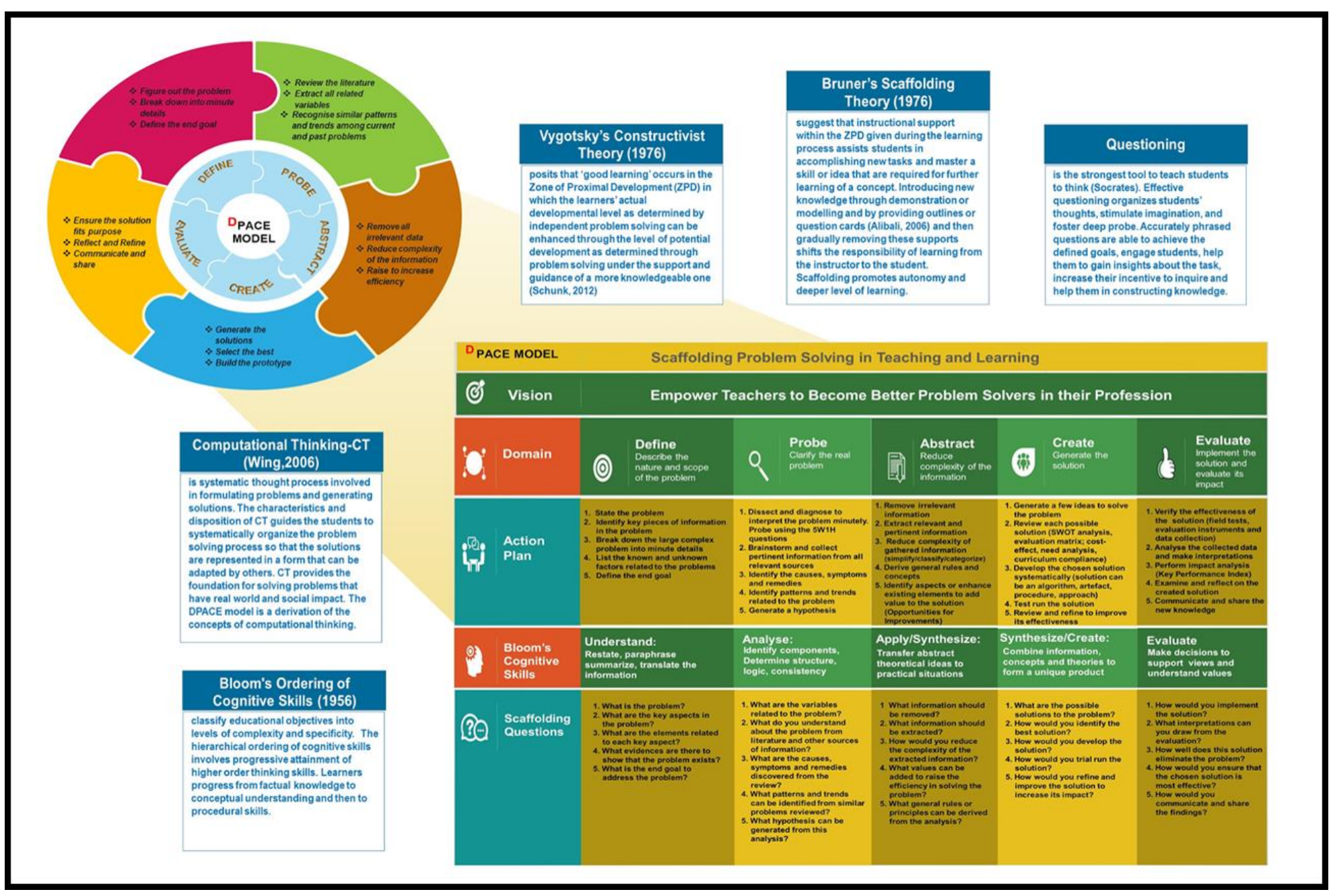


Govindasamy, M. K., \& Kwe, N. M. (2020). Scaffolding Problem Solving in Teaching and Learning the DPACE Model - A Design Thinking Approach.

Appendix 2

Likert Scale Questionnaire on the impact of the DPACE model on problem solving

\begin{tabular}{|c|c|c|c|c|c|c|}
\hline No & Questions & $\begin{array}{l}\text { Strongly } \\
\text { Agree \& } \\
\text { Agree }\end{array}$ & $\begin{array}{l}\text { Not } \\
\text { Sure }\end{array}$ & $\begin{array}{l}\text { Strongly } \\
\text { Disagree } \\
\& \\
\text { Disagree }\end{array}$ & Mean & $\begin{array}{l}\text { Standard } \\
\text { Deviation } \\
\text { (SD) }\end{array}$ \\
\hline 1 & $\begin{array}{l}\text { The } 5 \text { domains in the } \mathrm{CT} \text { helped } \\
\text { me to understand the } \\
\text { hierarchical processes of problem } \\
\text { solving. }\end{array}$ & $\begin{array}{l}94.74 \\
(36)\end{array}$ & $\begin{array}{l}5.26 \\
(2)\end{array}$ & 0 & 4.18 & 0.51 \\
\hline 2 & $\begin{array}{l}\text { I'm clear with the end goal of } \\
\text { each domain. }\end{array}$ & $\begin{array}{l}73.68 \\
(28)\end{array}$ & $\begin{array}{l}23.68 \\
(9)\end{array}$ & $\begin{array}{l}2.63 \\
(1)\end{array}$ & 3.95 & 0.77 \\
\hline 3 & $\begin{array}{l}\text { The questions in each domain are } \\
\text { clear and comprehensible. }\end{array}$ & $\begin{array}{l}84.21 \\
(32)\end{array}$ & $\begin{array}{l}10.53 \\
(4)\end{array}$ & $\begin{array}{l}5.26 \\
(2)\end{array}$ & 3.97 & 0.72 \\
\hline 4 & $\begin{array}{l}\text { The questions enabled me to } \\
\text { understand what is to be done at } \\
\text { each domain. }\end{array}$ & $\begin{array}{l}84.21 \\
(32)\end{array}$ & $\begin{array}{l}10.53 \\
(4)\end{array}$ & $\begin{array}{l}5.26 \\
(2)\end{array}$ & 4.00 & 0.84 \\
\hline 5 & $\begin{array}{l}\text { The questions helped me to } \\
\text { decompose the problems better. }\end{array}$ & $\begin{array}{l}89.47 \\
(34)\end{array}$ & $\begin{array}{l}7.89 \\
(3)\end{array}$ & $\begin{array}{l}2.63 \\
(1)\end{array}$ & 4.24 & 0.71 \\
\hline 6 & $\begin{array}{l}\text { The questions helped me to } \\
\text { probe the cause of the problem. }\end{array}$ & $\begin{array}{l}86.84 \\
(33)\end{array}$ & $\begin{array}{l}10.53 \\
(4)\end{array}$ & $\begin{array}{l}2.63 \\
(1)\end{array}$ & 4.13 & 0.7 \\
\hline 7 & $\begin{array}{l}\text { The questions helped me to } \\
\text { explore symptoms and remedies } \\
\text { for the problem. }\end{array}$ & $\begin{array}{l}86.84 \\
(33)\end{array}$ & $\begin{array}{l}10.53 \\
(4)\end{array}$ & $\begin{array}{l}2.63 \\
(1)\end{array}$ & 4.16 & 0.72 \\
\hline 8 & $\begin{array}{l}\text { The questions helped me to } \\
\text { organize my problem solving } \\
\text { process systematically. }\end{array}$ & $\begin{array}{l}94.74 \\
(36)\end{array}$ & $\begin{array}{l}2.63 \\
(1)\end{array}$ & $\begin{array}{l}2.63 \\
(1)\end{array}$ & 4.29 & 0.65 \\
\hline 9 & $\begin{array}{l}\text { I'm able to create a solution to } \\
\text { the problem. }\end{array}$ & $\begin{array}{l}92.11 \\
(35)\end{array}$ & $\begin{array}{l}5.26 \\
(2)\end{array}$ & $\begin{array}{l}2.63 \\
(1)\end{array}$ & 4.26 & 0.69 \\
\hline 10 & $\begin{array}{l}\text { The scaffolding provided through } \\
\text { the questions helped me to } \\
\text { create a practical solution to the } \\
\text { teaching and learning problem. }\end{array}$ & $\begin{array}{l}81.58 \\
(31)\end{array}$ & $\begin{array}{l}13.16 \\
(5)\end{array}$ & $\begin{array}{l}5.26 \\
(2)\end{array}$ & 4.16 & 0.82 \\
\hline
\end{tabular}


Govindasamy, M. K., \& Kwe, N. M. (2020). Scaffolding Problem Solving in Teaching and Learning the DPACE Model - A Design Thinking Approach.

\begin{tabular}{|c|c|c|c|c|c|c|}
\hline No & Questions & $\begin{array}{l}\text { Strongly } \\
\text { Agree \& } \\
\text { Agree }\end{array}$ & $\begin{array}{l}\text { Not } \\
\text { Sure }\end{array}$ & $\begin{array}{l}\text { Strongly } \\
\text { Disagree } \\
\& \\
\text { Disagree }\end{array}$ & Mean & $\begin{array}{l}\text { Standard } \\
\text { Deviation } \\
\text { (SD) }\end{array}$ \\
\hline 11 & $\begin{array}{l}\text { The scaffolding provided through } \\
\text { the questions helped me to } \\
\text { create a justifiable solution to the } \\
\text { teaching and learning problem. }\end{array}$ & $\begin{array}{l}86.84 \\
(33)\end{array}$ & $\begin{array}{l}7.89 \\
(3)\end{array}$ & $\begin{array}{l}5.26 \\
(2)\end{array}$ & 4.21 & 0.7 \\
\hline 12 & $\begin{array}{l}\text { The scaffolding helped me to } \\
\text { develop my problem-solving } \\
\text { skills. }\end{array}$ & $\begin{array}{l}84.21 \\
(32)\end{array}$ & $\begin{array}{l}10.53 \\
(4)\end{array}$ & $\begin{array}{l}5.26 \\
(2)\end{array}$ & 4.08 & 0.78 \\
\hline 13 & $\begin{array}{l}\text { The guidance provided through } \\
\text { the scaffolding helped me to } \\
\text { become better problem solver. }\end{array}$ & $\begin{array}{l}78.95 \\
(30)\end{array}$ & $\begin{array}{l}13.16 \\
(5)\end{array}$ & $\begin{array}{l}7.89 \\
(3)\end{array}$ & 4.03 & 0.88 \\
\hline 14 & $\begin{array}{l}\text { With scaffolding, I'm able to } \\
\text { make rational and intelligent } \\
\text { decisions regarding teaching and } \\
\text { learning problems. }\end{array}$ & $\begin{array}{l}92.11 \\
(35)\end{array}$ & $\begin{array}{l}5.26 \\
(2)\end{array}$ & $\begin{array}{l}2.63 \\
(1)\end{array}$ & 4.18 & 0.65 \\
\hline \multirow[t]{2}{*}{15} & $\begin{array}{l}\text { I believe I can solve teaching and } \\
\text { learning related problems better } \\
\text { now. }\end{array}$ & $\begin{array}{l}89.47 \\
(34)\end{array}$ & $\begin{array}{l}10.53 \\
(4)\end{array}$ & 0.00 & 4.18 & 0.61 \\
\hline & Average & 86.67 & 9.82 & 3.51 & 4.14 & 0.72 \\
\hline
\end{tabular}

